\title{
PREDIKSI PENYAKIT TUBERCULOSIS (TBC) MENGGUNAKAN ALGORITMA C4.5
}

\author{
Deny Febriyanto ${ }^{1)}$, Yogiek Indra Kurniawan ${ }^{2)}$ \\ ${ }^{1,2)}$ Program Studi Informatika, Universitas Muhammadiyah Surakarta \\ 1) denyfebriant@hotmail.com, ${ }^{2)}$ yogiek@ums.ac.id
}

\begin{abstract}
Tuberculosis (TB) is an infectious disease caused bymycobacteria especially Mycobacterium tuberculosis. TB disease remains on eof the threats, especially in a country with low and middle economic level. According to World Health Organization (WHO), TB disease became one of the biggest causes of death in the world. Indonesia ranks second with the largest number of TB cases in the world. In addition, there are some symptoms and factors that can cause a person affected by $T B$ disease. The treatment of TB disease can be done intensively but takes a long time. Research in the diagnosis of disease with classification techniques using $C 4.5$ algorithm has been done by several previous researchers and get good results. Therefore, this research will predict TB disease using C4.5 algorithm. with high precision accuracy.The C4.5 algorithm is chosen because it is is very easy, fast and has high precision accuracy. The result of the study is an application that can help people to make the diagnosis of TB disease from early age.

Keywords : Data Mining, C4.5, Prediction of Disease, Tuberculosis
\end{abstract}

\section{PENDAhULUAN}

Penyakit Tuberculosis (TBC) adalah penyakit menular yang disebabkan oleh mycobacteria, terutama Mycobacteriumtuberculosis (Ekata et al, 2016). Penyakit ini dapat menyebar dari orang ke orang melalui udara (Zulfia et al, 2017). Penyakit TBC saat ini masih menjadi salah satu ancaman penyakit yang perlu diwaspadai, terutama di suatu negara dengan perekonomian rendah dan menengah (Cheon et al, 2016).

Menurut World Health Organization (WHO) penyakit TBC menjadi salah satu penyebab kematian terbesar di dunia, pada tahun 2015 sebanyak 1.57 juta meninggal karena penyakit TBC (WHO, 2016). Di Indonesia, ditemukan pengidap Tuberculosis (TBC) pada tahun 2015 sebanyak 330.910 kasus. Meningkat 1,96 persen dari tahun sebelumnya, sebanyak 324.539 kasus (Kemenkes, 2016). Selain itu, WHO Tuberculosis Report 2016 menyatakan indonesia menempati urutan kedua dengan jumlah kasus TBC terbanyak di dunia (WHO, 2016).

Ada beberapa gejala yang dapat menyebabkan timbulnya penyakit TBC diantaranya demam, batuk, nyeri dada, sesak nafas, dahak disertai darah, nafsu makan menurun, berat badan menurun, dan berkeringkat dimalam hari (Padila, 2013). Selain itu, ada 2 faktor yang mempengaruhi yaitu faktor resiko dan faktor lingkungan. Faktor resiko antara lain HIV, riwayat penyakit diabetes melitus, dan merokok (WHO, 2015). Untuk faktor lingkungan meliputi kelembaban udara dan keadaan rumah (Kemenkes, 2014). Sedangkan untuk mengobati penyakit TBC dapat dilakukan secara intensif. Tetapi membutuhkan waktu lama, yaitu 12 minggu (fase awal) dan $4-6$ bulan (fase lanjutan) untuk pemulihan (Ethica et al, 2014).

Dapat disimpulkan bahwa penyakit TBC ini tergolong penyakit menular berbahaya terutama di Indonesia. Untuk penyembuhannya membutuhkan waktu yang cukup lama, serta belum adanya alat yang memadai untuk melakukan prediksi penyakit TBC (Deliu \& Manea, 2014). Maka dari itu, perlu adanya aplikasi yang dapat digunakan untuk 
mempermudah prediksi penyakit TBC. Salah satu teknik yang dapat digunakan untuk melakukan prediksi penyakit adalah klasifikasi. Klasifikasi adalah salah satu teknik yang ada dalam data mining, membutuhkan pohon keputusan untuk membuat data dalam grup atau kelas (Adhatrao et al, 2013).

Banyak penelitian prediksi penyakit dengan teknik klasifikasi, diantaranya dilakukan oleh Purushottam et al (2016) dalam prediksi penyakit jantung menggunakan Decision Tree (C4.5) dan hasil dari penelitian tersebut algoritma Decision Tree (C4.5) menghasilkan nilai terbaik. Selain itu, penelitian lain yang dilakukan Kumar \& Umatejaswi (2017) dengan melakukan komparasi 4 algoritma, yaitu Naive Bayes, Random Tree, C4.5 dan Simple Logistics untuk diagnosis penyakit diabetes dengan total 650 kasus dan 14 attribut. Hasil dari penelitian tersebut juga menyatakan algoritma $\mathrm{C} 4.5$ menghasilkan nilai terbaik, dengan nilai akurasi 100 dan error rate 0. Algoritma C4.5 banyak digunakan di dalam klasifikasi karena sangat mudah di interpretasikan, cepat, serta memiliki akurasi presisi tinggi (Kamagi \& Hansun, 2014).

Berdasarkan telaah diatas, dalam penelitian ini akan menggunakan algoritma C4.5 dalam prediksi penyakit TBC. Dari pengolahan algoritma C4.5 didapatkan pohon keputusan, kemudian akan diinterpretasikan kedalam aturan-aturan keputusan (rules) yang dapat digunakan sebagai acuan untuk melakukan prediksi penyakit TBC.

\section{METODE PENELITIAN}

Metodologi yang akan digunakan dalam penelitian ini dapat dilihat pada Gambar 1.

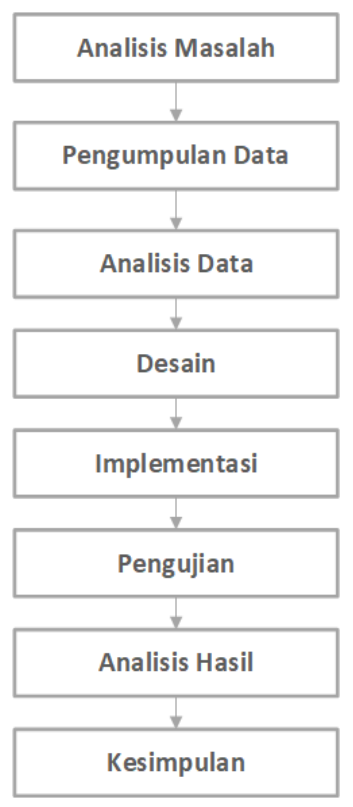

Gambar 1. Tahapan Metodologi Penelitian

\subsection{Analisis Masalah}

Pada tahap ini bertujuan untuk mengidentifikasikan permasalahan-permasalahan yang muncul dari adanya penyakit TBC. Diantaranya, penyakit TBC ini tergolong penyakit menular berbahaya terutama di Indonesia. Untuk penyembuhannya membutuhkan waktu yang cukup lama, serta belum adanya alat yang memadai untuk melakukan prediksi penyakit TBC. Berdasarkan permasalahan yang ada, dibutuhkan aplikasi yang dapat digunakan untuk melakukan prediksi penyakit TBC. 


\subsection{Pengumpulan Data}

Data yang akan digunakan dalam penelitian ini yaitu data medis pasien yang didapatkan dari Balai Kesehatan Paru Masyarakat Surakarta, total ada 280 kasus dengan jumlah pasien terkena penyakit TBC ada 167 kasus, dan pasien yang tidak terkena TBC ada 113 kasus.

\subsection{Analisis Data}

Data yang didapatkan, kemudian dianalisa untuk menentukan variabel - variabel yang digunakan dalam pembuatan aplikasi. Variabel yang diperlukan dalam penelitian ini, dapat dilihat pada Tabel 1.

Tabel 1. Variabel Penelitian

\begin{tabular}{|l|l|l|}
\hline Variabel & Tipe & Value \\
\hline X1 Merokok & Binomial & YA, TIDAK \\
\hline X2 Kelembaban Udara & Binomial & LEMBAB, TIDAKLEMBAB \\
\hline X3 Keadaan Rumah & Binomial & BERSIH, KOTOR \\
\hline X4 Diabetes Melitus & Binomial & YA, TIDAK \\
\hline X5 HIV & Binomial & YA, TIDAK \\
\hline X6 Batuk $\geq 3$ Minggu & Binomial & YA, TIDAK \\
\hline X7 Sesak Nafas & Binomial & YA, TIDAK \\
\hline X8 Nyeri Dada & Binomial & YA, TIDAK \\
\hline X9 Dahak Disertai Darah & Binomial & YA, TIDAK \\
\hline X10 Demam & Binomial & YA, TIDAK \\
\hline X11 Nafsu Makan Menurun & Binomial & YA, TIDAK \\
\hline X12 Berat Badan Menurun & Binomial & YA, TIDAK \\
\hline X13 Keringat di Malam Hari & Binomial & YA, TIDAK \\
\hline Y Terdiagnosa TBC & Binomial & YA, TIDAK \\
\hline
\end{tabular}

\subsection{Desain}

Tahap ini bertujuan untuk menggambarkan seperti apa rancangan dari aplikasi yang akan dibuat menggunakan algoritma C4.5. Rancangan aplikasi akan diintepretasikan dalam use case diagram. Use case diagram dapat dilihat pada Gambar 2. 


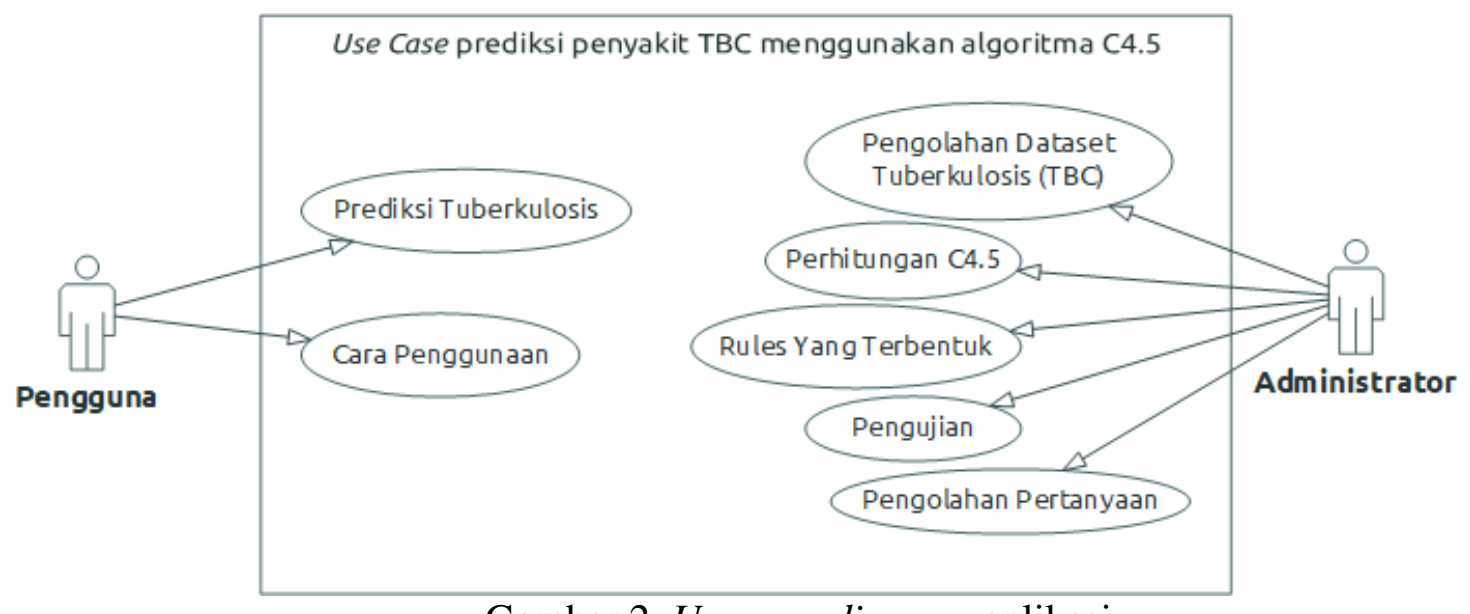

Gambar 2. Use case diagram aplikasi

Ada 2 aktor yang terlibat ke dalam aplikasi, yaitu Pengguna dan Administrator. Berikut ini penjelasan mengenai use case diagram dari kedua aktor diatas :

\section{a. Pengguna}

1. Prediksi Tuberkulosis

Pengguna dapat melakukan proses prediksi penyakit TBC.

2. Cara Penggunaan

\section{b. Administrator}

Pengguna dapat mengetahui cara penggunaan aplikasi.

1. Pengolahan Dataset Tuberkulosis (TBC)

Administrator dapat melakukan pengolahan dataset sesuai atribut yang dibutuhkan meliputi créate, read, update, delete (CRUD) dengan cara import file excel ataupun memasukkan data satu - satu.

2. Perhitungan $\mathrm{C} 4.5$

Administrator dapat melakukan proses perhitungan dari dataset yang ada menggunakan algoritma C4.5.

3. Rules Yang Terbentuk

Administrator dapat melihat rules yang didapatkan dari proses perhitungan C4.5.

4. Pengujian

Administrator dapat melakukan pengujian rules yang didapatkan menggunakan data training meliputi créate, read, update, delete (CRUD), dengan cara import file excel ataupun memasukkan data satu - satu.

5. Pengolahan Pertanyaan

Administrator dapat melakukan pengolahan pertanyaan - pertanyaan yang akan

\subsection{Implementasi} diajukan kepada pengguna.

Tahap ini aplikasi mulai dibangun dengan mengimplementasikan desain yang sudah dibuat. Aplikasi akan dibuat dalam model web based menggunakan bahasa pemrograman PHP. Sedangkan untuk Database Management System (DBMS) akan menggunakan MySQL. Aplikasi ini dapat dibuka menggunakan web browser maupun menggunakan handphone dan tablet yang terhubung ke internet (Kurniawan \& Dwiyatmika, 2017). Serta algoritma yang akan digunakan adalah algoritma C4.5.

Menurut Marwana (2014) algoritma C4.5 merupakan algoritma yang digunakan untuk membangun decision tree (pengambilan keputusan). Algoritma C4.5 adalah salah satu 
algoritma induksi pohon keputusan yaitu ID3 (Iterative Dichotomiser 3). ID3 dikembangan oleh J. Ross Quinlan. Dalam prosedur algoritma ID3, input berupa sampel training, label training dan atribut. Algoritma C4.5 ini merupakan pengembangan dari ID3. Selain itu menurut Harryanto \& Hansun (2017) ide dasar dari algoritma ini adalah pembuatan pohon keputusan berdasarkan pemilihan atribut yang memiliki prioritas tertinggi atau dapat disebut memiliki nilai gain tertinggi berdasarkan nilai entropy atribut tersebut sebagai poros atribut klasifikasi. Kemudian secara rekursif cabang-cabang pohon diperluas sehingga seluruh pohon terbentuk. Untuk memudahkan penjelasan mengenai algoritma C4.5. Berikut ini disertakan contoh dalam Tabel 2. Diambil 10 kasus secara acak, dari data medis pasien yang didapatkan dari Balai Kesehatan Paru Masyarakat Surakarta.

Tabel 2. Contoh Keputusan Penyakit TBC

\begin{tabular}{|c|c|c|c|c|c|c|c|c|c|c|c|c|c|}
\hline merokok & kelembabanudara & keadaanrumah & diabetes & HIV & batuk $\geq 3$ minggu & sesaknafas & nyeridada & dahak & demam & nafsumakan & beratbedan & keringat & TBC \\
\hline TIDAK & TIDAKLEMBAB & BERSIH & TIDAK & YA & YA & TIDAK & YA & TIDAK & TIDAK & TIDAK & TIDAK & TIDAK & YA \\
\hline TIDAK & TIDAKLEMBAB & BERSIH & TIDAK & TIDAK & YA & YA & YA & YA & YA & YA & YA & YA & YA \\
\hline TIDAK & TIDAKLEMBAB & BERSIH & TIDAK & YA & YA & TIDAK & TIDAK & YA & TIDAK & YA & YA & TIDAK & YA \\
\hline TIDAK & TIDAKLEMBAB & BERSIH & TIDAK & YA & YA & YA & YA & YA & YA & YA & YA & YA & YA \\
\hline TIDAK & TIDAKLEMBAB & BERSIH & TIDAK & TIDAK & YA & YA & TIDAK & TIDAK & YA & YA & YA & YA & YA \\
\hline YA & TIDAKLEMBAB & BERSIH & YA & TIDAK & TIDAK & TIDAK & TIDAK & TIDAK & TIDAK & TIDAK & TIDAK & TIDAK & TIDAK \\
\hline YA & TIDAKLEMBAB & KOTOR & TIDAK & TIDAK & TIDAK & TIDAK & TIDAK & TIDAK & TIDAK & TIDAK & TIDAK & TIDAK & TIDAK \\
\hline TIDAK & LEMBAB & KOTOR & TIDAK & TIDAK & TIDAK & TIDAK & YA & TIDAK & TIDAK & YA & YA & TIDAK & TIDAK \\
\hline TIDAK & TIDAKLEMBAB & BERSIH & TIDAK & TIDAK & TIDAK & TIDAK & TIDAK & TIDAK & TIDAK & TIDAK & TIDAK & TIDAK & TIDAK \\
\hline YA & TIDAKLEMBAB & BERSIH & TIDAK & TIDAK & TIDAK & TIDAK & YA & TIDAK & YA & TIDAK & TIDAK & TIDAK & TIDAK \\
\hline
\end{tabular}

Dalam contoh kasus yang tertera dalam Tabel 2, akan didapatkan rules hasil dari pembuatan pohon keputusan untuk menentukan pasien terkena TBC atau tidak. Berdasarkan apa yang ditulis oleh Hanik Umi (2011), terdapat empat langkah dalam proses pembuatan pohon keputusan pada algoritma $\mathrm{C} 4.5$, yaitu:

a. Memilih atribut sebagai akar.

b. Membuat cabang untuk masing-masing nilai.

c. Membagi setiap kasus dalam cabang.

d. Mengulangi proses dalam setiap cabang sehingga semua kasus dalam cabang memiliki kelas yang sama.

Data yang dimiliki harus disusun menjadi sebuah tabel berdasarkan kasus sebelum dilakukan perhitungan untuk mencari nilai entropy dan gain. Berikut ini rumus untuk mencari nilai entropy dan gain.

$\operatorname{Entropy}(S)=\sum_{\mathrm{j}=1}^{\mathrm{k}}-p j \log _{2} p j$

Rumus (1) merupakan rumus yang digunakan dalam perhitungan entropy yang digunakan untuk menentukan heterogenity dari sebuah kumpulan data sample (Amin et al, 2015). Berikut keterangannya :

$S$ : Himpunan kasus

$k$ : Jumlah partisi $\mathrm{S}$

pj : Jumlah kasus pada partisi ke-j

$\operatorname{Gain}(A)=\operatorname{Entropy}(S)-\sum_{\mathrm{i}=1}^{\mathrm{k}} \frac{\left|S_{i}\right|}{|S|} \times \operatorname{Entropy}\left(S_{i}\right)$

Rumus (2) merupakan rumus yang digunakan dalam perhitungan gain setelah melakukan perhitungan entropy. Berikut keterangannya :

$A$ : Atribut dari dataset

$k$ : Jumlah partisi $S$

$S$ : Himpunan kasus 
Dengan mengetahui rumus-rumus diatas, data yang telah diperoleh dapat dimasukkan dan diproses dengan algoritma C4.5 untuk proses pembuatan decision tree. Berikut ini adalah penjelasan lebih rinci mengenai masing - masing langkah dalam pembentukan pohon keputusan dengan menggunakan algoritma $\mathrm{C} 4.5$ untuk menyelesaikan permasalahan pada Tabel 2.

a. Menghitung jumlah kasus, jumlah kasus untuk keputusan YA, jumlah kasus untuk keputusan TIDAK, dan entropy dari semua kasus. Kasus dibagi berdasarkan atribut yang ada. Setelah itu dilakukan perhitungan gain untuk masing - masing atribut. Hasil perhitungan ditunjukkan dalam Tabel 3.

Tabel 3. Contoh Perhitungan Node 1

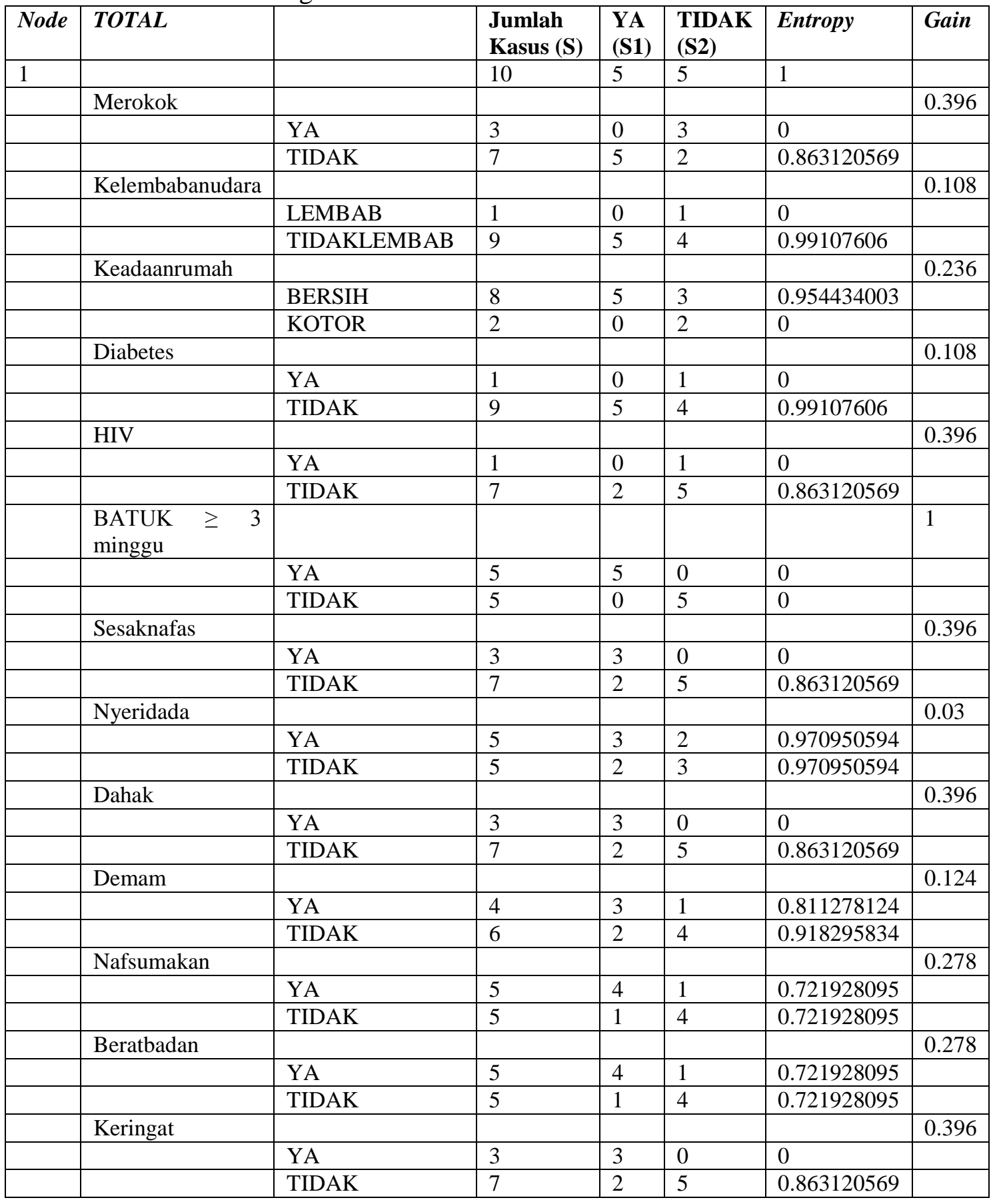


Baris TOTAL kolom entropy pada Tabel 3 dihitung dengan rumus 1, sebagai berikut:

$\operatorname{Entropy}($ Total $)=\left(-\frac{5}{10} \times \log _{2}\left(\frac{5}{10}\right)\right)+\left(-\frac{5}{10} \times \log _{2}\left(\frac{5}{10}\right)\right)$

Entropy $($ Total $)=1$

Sementara itu nilai gain pada baris Merokok dihitung dengan menggunakan rumus 2, sebagai berikut :

$$
\begin{aligned}
& \operatorname{Gain}(A)=\operatorname{Entropy}(\text { Total })-\sum_{\mathrm{i}=1}^{\mathrm{k}} \frac{\mid \text { Merokok }_{i} \mid}{\mid \text { Total }} \times \operatorname{Entropy}\left(\text { Merokok }_{i}\right) \\
& \operatorname{Gain}(A)=1-\left(\left(\frac{3}{10} \times 0\right)+\left(\frac{7}{10} \times 0.863120569\right)\right) \\
& \operatorname{Gain}(A)=0.396
\end{aligned}
$$

b. Dari hasil pada Tabel 3 dapat diketahui bahwa atribut dengan nilai gain tertinggi adalah BATUK $\geq 3$ MINGGU yaitu sebesar 1 . Dengan demikian BATUK $\geq 3$ MINGGU dapat menjadi node akar. Ada 2 nilai atribut dari BATUK $\geq 3$ MINGGU yaitu YA dan TIDAK. Dari kedua nilai atribut tersebut, nilai atribut YA dan TIDAK sudah mengklasifikasikan kasus menjadi satu. Sehingga tidak perlu dilakukan perhitungan lebih lanjut. Dan hasil pohon keputusan yang terbentuk, seperti berikut ini :

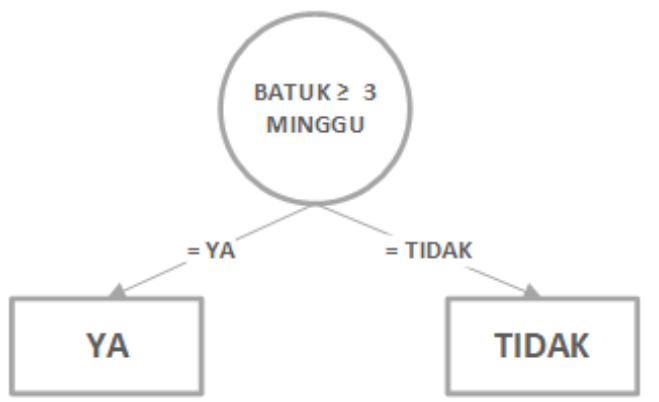

Gambar 3. Contoh Pohon Keputusan Hasil Perhitungan Node 1

c. Dengan memperhatikan pohon keputusan pada Gambar 3, diketahui bahwa semua kasus sudah masuk dalam kelas. Dengan demikian, pohon keputusan pada Gambar 3 merupakan pohon keputusan terakhir yang terbentuk. Dari pohon keputusan pada Gambar 3, didapatkan 2 rules pada Tabel 4.

Tabel 4. Contoh rules yang terbentuk dari pohon keputusan

\begin{tabular}{|l|l|}
\hline no & \multicolumn{1}{c|}{ rules yang terbentuk } \\
\hline 1 & IF BATUK $\geq 3 \mathrm{MINGGU}=$ YA THEN TBC $=$ YA \\
\hline 2 & IF BATUK $\geq 3 \mathrm{MINGGU}=$ TIDAK THEN TBC $=$ TIDAK \\
\hline
\end{tabular}

\subsection{Pengujian}

Pada tahap ini, pengujian dilakukan bertujuan untuk mengetahui apakah aplikasi yang telah dibuat sesuai dengan design yang direncanakan, menguji fitur - fitur yang ada sesuai sebagaimana semestinya, menguji aplikasi dengan beberapa model data uji untuk membandingkan nilai precision, recall, dan accuracy. Menurut Han et al (2011) untuk menghitung akurasi dapat digunakan tabel confusion matrix pada Tabel 5 berikut :

Tabel 5. Panduan Menghitung Precision, Recall, dan Accuracy

\begin{tabular}{|l|l|l|l|}
\hline \multirow{2}{*}{$\begin{array}{c}\text { Kelas } \\
\text { Sebenarnya }\end{array}$} & \multicolumn{2}{|l|}{ Kelas Prediksi } & \multirow{2}{*}{ Total } \\
\cline { 2 - 3 } & yes & no & (False \\
\hline yes & TP (True Positive) & $\begin{array}{l}\text { FN } \\
\text { Negative })\end{array}$ & \\
\hline no & FP (False Positive) & TN (True Negative) $)$ & $\mathrm{N}$ \\
\hline Total & P' & N' & $\mathrm{P}+\mathrm{N}$ \\
\hline
\end{tabular}


Untuk nilai precision, recall, dan accuracy dapat dihitung dengan rumus sebagai berikut ini:

$$
\begin{aligned}
& \text { Precision }=\frac{T P}{T P+F P} \\
& \text { Recall }=\frac{T P}{T P+F N} \\
& \text { Accuracy }=\frac{T P+T N}{P+N}=\frac{T P+T N}{T P+F N+F P+T N}
\end{aligned}
$$

\subsection{Analisis Hasil}

Setelah pengujian pada aplikasi berhasil dilakukan, selanjutnya akan dilakukan pengukuran tingkat akurasi prediksi dari aplikasi yang telah dibuat.

\subsection{Kesimpulan}

Pada tahap ini, penulis akan memberikan hasil simpulan dari semua proses yang dilakukan dalam penelitian ini.

\section{HASIL DAN PEMBAHASAN}

Hasil dan pembahasan dari penelitian yang dilakukan adalah sebagai berikut :

\subsection{Implementasi Aplikasi}

Pada bagian implementasi aplikasi akan dijelaskan beberapa menu yang ada pada aplikasi yang telah dibuat. Aplikasi prediksi penyakit tuberkulosis (TBC) ini terdapat 2 aktor. Dimana tiap aktor memiliki fitur masing - masing, diantaranya sebagai berikut :

\section{a. Administrator}

1. Dataset Tuberkulosis (TBC)

Pada menu Dataset Tuberkulosis (TBC), administrator dapat mengolah dataset tuberkulosis (TBC). Meliputi edit, hapus, dan tambah data kasus. Khusus untuk tambah data kasus bisa melalui import file excel ataupun menambahkannya satu per-satu.

\section{Perhitungan $\mathrm{C} 4.5$}

Pada bagian perhitungan $\mathrm{C} 4.5$ ini, dapat dilakukan proses perhitungan $\mathrm{C} 4.5$ dari data training yang telah ada. Untuk mendapatkan rules yang akan digunakan dalam proses Prediksi Penyakit Tuberkulosis (TBC).

3. Rules Yang Terbentuk

Pada menu ini, akan didapatkan beberapa rules atau aturan yang dapat digunakan untuk melakukan Prediksi Penyakit Tuberkulosis (TBC).

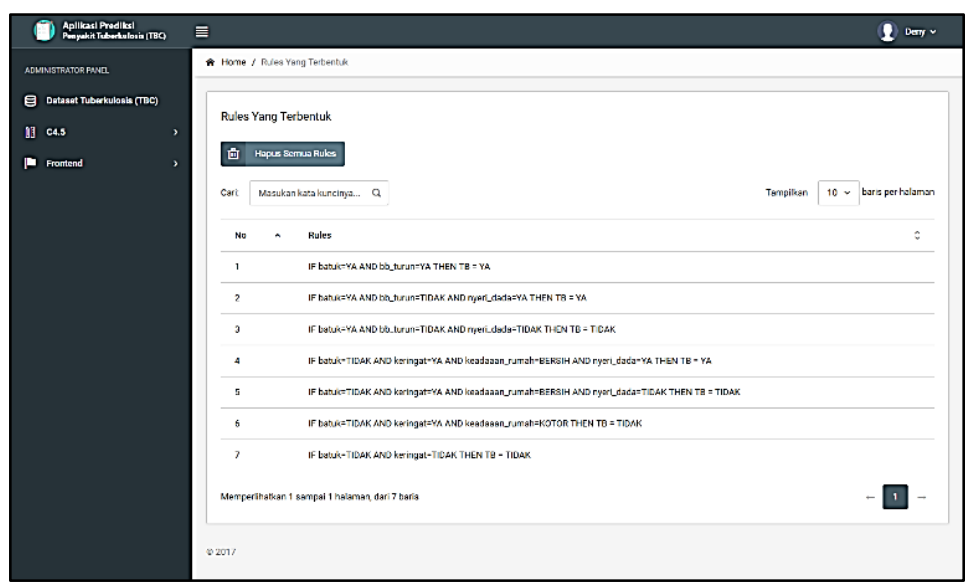

Gambar 4. Tampilan Menu Rules Yang Terbentuk 
4. Pengujian

Pada menu Pengujian, administrator dapat mengolah data uji. Meliputi edit, hapus, dan tambah kasus uji. Khusus tambah kasus uji dapat dilakukan dengan 2 cara, yaitu melalui import file excel ataupun menambahkan kasus uji satu per-satu. Setelah selesai menambahkan data uji, administrator dapat melakukan pengujian dari data uji yang telah dimasukkan berdasarkan rules yang telah diperoleh. Dari proses pengujian, akan diperoleh seberapa ketepatan proses pengujian dan hasil nilai Precision, Recall, dan Accuracy.

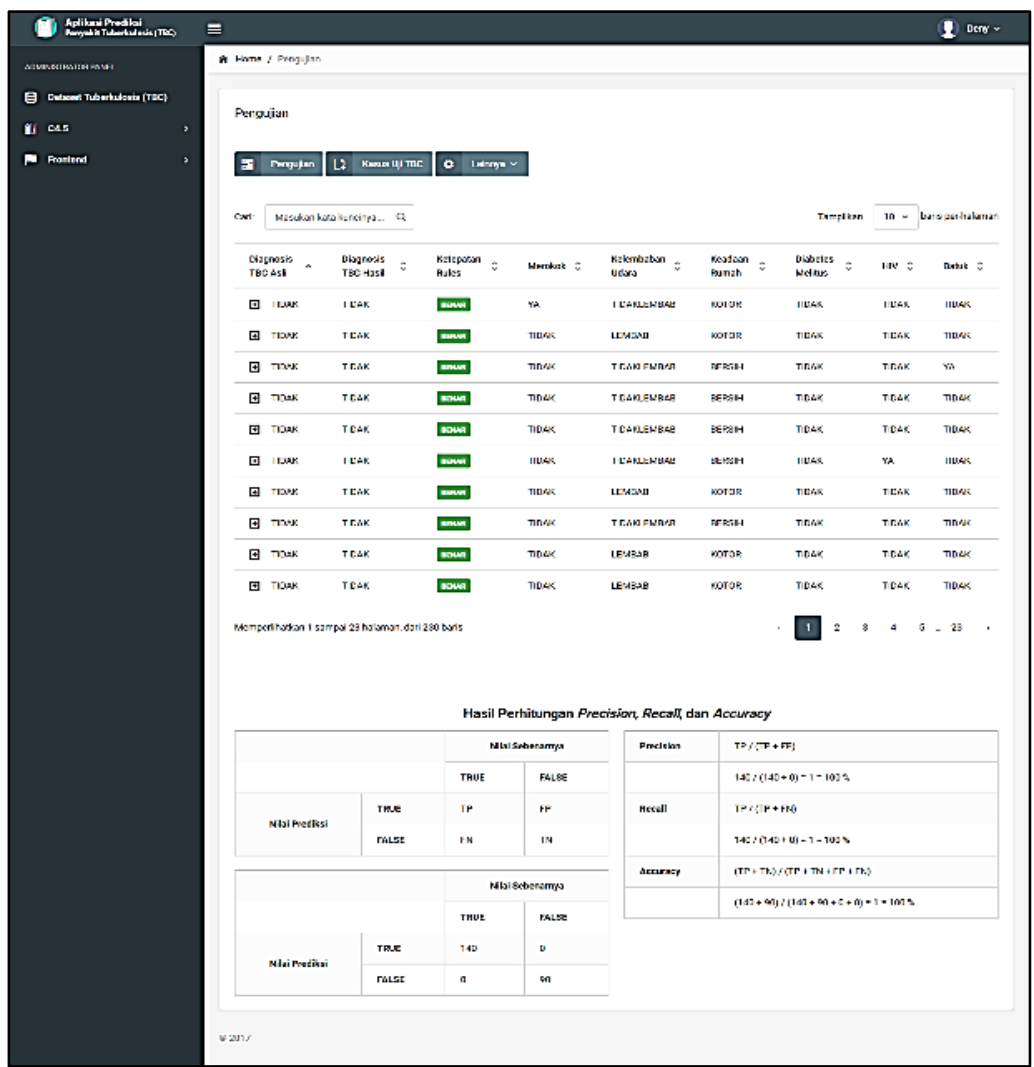

Gambar 5. Tampilan Menu Pengujian

5. Pengolahan Pertanyaan

Untuk bagian pengolahan pertanyaan, administrator dapat merubah pertanyaan -

b. Pengguna pertanyaan yang akan diajukan ke pada pengguna.

1. Halaman Depan (frontend)

Di Halaman Depan (frontend) ini, pengguna dapat melihat beberapa menu yang tersedia di aplikasi ini antara lain Beranda, Apa itu Tuberkulosis?, Penanganan Tuberkulosis, Cek Tuberkulosis dan Tentang. Halaman ini dibuat dalam model one page.

2. Prediksi Tuberkulosis (TBC)

Pada menu ini, pengguna dapat melakukan prediksi tuberkulosis (TBC) dengan cara menjawab semua pertanyaan yang ada (total ada 13 pertanyaan) sesuai kondisi yang dialami pengguna saat ini. Tiap jawaban yang diberikan, akan 
digunakan sebagai input dalam proses prediksi tuberkulosis berdasarkan rules yang telah diperoleh. Setelah menjawab semua pertanyaan yang ada, pengguna akan memperoleh hasil prediksi tuberkulosis (TBC). Apakah pengguna diprediksi terkena penyakit tuberkulosis atau tidak.

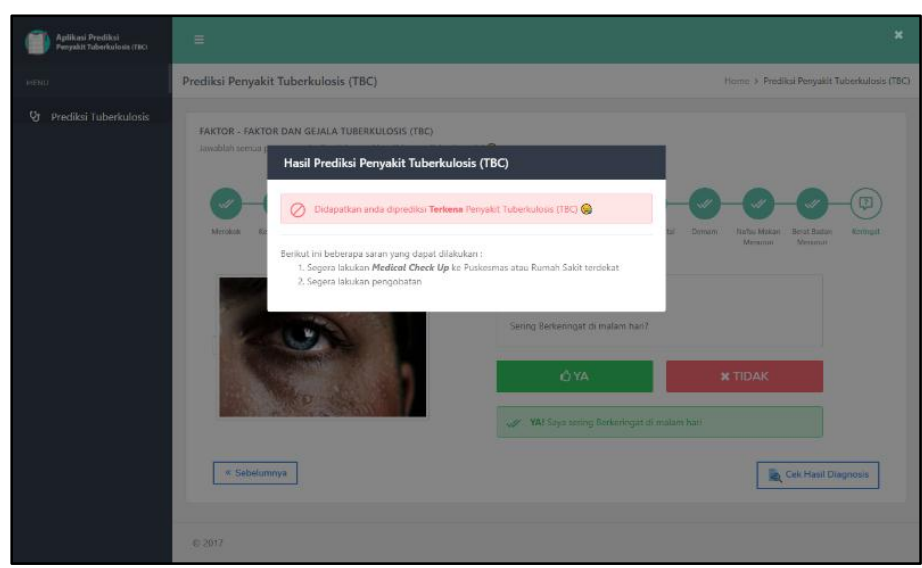

Gambar 6. Hasil Prediksi apabila pengguna diprediksi terkena Penyakit Tuberkulosis (TBC)

3. Cara Penggunaan

Di bagian menu Cara Penggunaan ini, pengguna dapat melihat seperti apa cara penggunaan dari aplikasi Prediksi Penyakit Tuberkulosis (TBC).

\subsection{Pengujian}

Pada bagian pengujian akan dilakukan beberapa tipe pengujian, meliput pengujian blackbox dan pengujian Precision, Recall, dan Accuracy.

\subsubsection{Pengujian Blackbox}

Pada bagian pengujian blackbox ini akan dilakukan pengujian mengenai fitur yang ada pada aplikasi, apakah sudah sesuai dengan hasil yang diharapkan atau tidak.

Tabel 6. Hasil Pengujian Blackbox

\begin{tabular}{|c|c|c|c|}
\hline Module/Menu/Fitur & Test Case & Hasil Yang Diharapkan & Hasil \\
\hline \multirow[t]{2}{*}{ Administrator - Login } & User \& Password Benar & $\begin{array}{l}\text { Muncul Notifikasi Berhasil } \\
\text { Login }\end{array}$ & Sesuai \\
\hline & User \& Password Salah & $\begin{array}{l}\text { Muncul Notifikasi } \text { Gagal } \\
\text { Login }\end{array}$ & Sesuai \\
\hline \multirow[t]{5}{*}{$\begin{array}{l}\text { Administrator - Dataset } \\
\text { Tuberkulosis (TBC) }\end{array}$} & Klik Tambah Kasus TBC & $\begin{array}{l}\text { Menampilkan Halaman } \\
\text { Tambah Kasus TBC }\end{array}$ & Sesuai \\
\hline & Klik Import Data TBC & $\begin{array}{l}\text { Menampilkan Modals Import } \\
\text { Data TBC }\end{array}$ & Sesuai \\
\hline & Klik Hapus Kasus TBC & $\begin{array}{l}\text { Menghapus Kasus TBC yang } \\
\text { terpilih }\end{array}$ & Sesuai \\
\hline & $\begin{array}{l}\text { Klik Hapus Semua Kasus } \\
\text { TBC }\end{array}$ & $\begin{array}{l}\text { Menghapus Semua Kasus } \\
\text { TBC yang ada }\end{array}$ & Sesuai \\
\hline & Klik Edit Kasus TBC & $\begin{array}{l}\text { Menampilkan halaman untuk } \\
\text { mengedit Kasus TBC yang } \\
\text { terpilih }\end{array}$ & Sesuai \\
\hline $\begin{array}{l}\text { Administrator } \\
\text { Perhitungan C4.5 }\end{array}$ & Klik Perhitungan C4.5 & $\begin{array}{l}\text { Memproses Kasus TBC yang } \\
\text { telah ada, untuk dihitung } \\
\text { menggunakan Algoritma C4.5 } \\
\text { sehingga didapatkan rules } \\
\text { atau aturan. }\end{array}$ & Sesuai \\
\hline
\end{tabular}




\begin{tabular}{|c|c|c|c|}
\hline Module/Menu/Fitur & Test Case & Hasil Yang Diharapkan & Hasil \\
\hline $\begin{array}{l}\text { Administrator - Rules } \\
\text { Yang Terbentuk }\end{array}$ & Klik Hapus Semua Rules & $\begin{array}{l}\text { Menghapus rules yang telah } \\
\text { diperoleh dari proses } \\
\text { perhitungan C4.5 }\end{array}$ & Sesuai \\
\hline \multirow[t]{6}{*}{$\begin{array}{l}\text { Administrator } \\
\text { Pengujian }\end{array}$} & Klik Tambah Kasus Uji TBC & $\begin{array}{l}\text { Menampilkan halaman } \\
\text { tambah kasus uji TBC }\end{array}$ & Sesuai \\
\hline & Klik Import Data Uji TBC & $\begin{array}{l}\text { Menampilkan Modals import } \\
\text { data uji TBC }\end{array}$ & Sesuai \\
\hline & Klik Hapus Data Uji TBC & 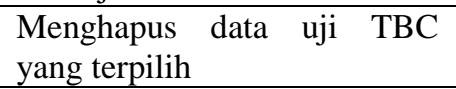 & Sesuai \\
\hline & $\begin{array}{l}\text { Klik Hapus Semua Data Uji } \\
\text { TBC }\end{array}$ & $\begin{array}{l}\text { Menghapus semua data uji } \\
\text { TBC yang ada }\end{array}$ & Sesuai \\
\hline & Klik Edit Data Uji TBC & $\begin{array}{l}\text { Menampilkan halaman untuk } \\
\text { mengedit data uji TBC }\end{array}$ & Sesuai \\
\hline & Klik Pengujian & $\begin{array}{l}\text { Melakukan Proses Pengujian } \\
\text { ke data kasus uji TBC yang } \\
\text { telah ada, sehingga } \\
\text { mendapatkan hasil Ketepatan } \\
\text { Prediksi. Serta nilai Precision, } \\
\text { Recall, Accuracy dan Error } \\
\text { Rate }\end{array}$ & Sesuai \\
\hline $\begin{array}{l}\text { Administrator } \\
\text { Pertanyaan Yang Ada }\end{array}$ & Klik Pertanyaan Yang Ada & $\begin{array}{l}\text { Menampilkan halaman berisi } \\
\text { pertanyaan dari tiap topik } \\
\text { yang akan diajukan ke } \\
\text { Pengguna, dan dapat } \\
\text { melakukan edit pertanyaan } \\
\text { tersebut. }\end{array}$ & Sesuai \\
\hline \multirow[t]{4}{*}{$\begin{array}{l}\text { Pengguna }- \text { Prediksi } \\
\text { Tuberkulosis }\end{array}$} & $\begin{array}{l}\text { Klik Opsi Jawaban di tiap } \\
\text { topik pertanyaan }\end{array}$ & $\begin{array}{l}\text { Muncul Message, mengenai } \\
\text { jawaban yang dipilih }\end{array}$ & Sesuai \\
\hline & Klik Selanjutnya & $\begin{array}{l}\text { Untuk lanjut ke pertanyaan } \\
\text { selanjutnya }\end{array}$ & Sesuai \\
\hline & Klik Sebelumnya & $\begin{array}{l}\text { Untuk balik ke pertanyaan } \\
\text { sebelumnya }\end{array}$ & Sesuai \\
\hline & Klik Cek Hasil Diagnosis & $\begin{array}{l}\text { Untuk memproses jawaban } \\
\text { yang telah dipilih pengguna, } \\
\text { sehingga didapatkan hasil } \\
\text { prediksi Tuberkulosis }\end{array}$ & Sesuai \\
\hline $\begin{array}{l}\text { Pengguna }- \\
\text { Penggunaan }\end{array}$ & - & $\begin{array}{l}\text { Menampilkan halaman cara } \\
\text { penggunaan aplikasi }\end{array}$ & Sesuai \\
\hline
\end{tabular}

\subsubsection{Pengujian Precision, Recall, dan Accuracy}

Dalam pengujian ini dilakukan dengan membagi data training dan data testing yang telah diperoleh dari Balai Kesehatan Paru Masyarakat Surakarta berjumlah 280 kasus menjadi beberapa bagian secara acak. Di tiap bagian terdapat 3 kali proses pengujian, dan hasil yang didapatkan adalah nilai rata-rata dari ke 3 proses pengujian tersebut.

Tabel 7. Hasil Pengujian Precision, Recall, dan Accuracy

\begin{tabular}{|l|l|l|l|l|}
\hline Data Training & Data Testing & Precision & Recall & Accuracy \\
\hline 50 & 230 & $97,67 \%$ & $100 \%$ & $98,67 \%$ \\
\hline 100 & 180 & $99 \%$ & $100 \%$ & $99,3 \%$ \\
\hline 150 & 130 & $100 \%$ & $100 \%$ & $100 \%$ \\
\hline 200 & 80 & $100 \%$ & $100 \%$ & $100 \%$ \\
\hline 250 & 30 & $100 \%$ & $100 \%$ & $100 \%$ \\
\hline
\end{tabular}


Dari hasil pengujian Precison, Recall, dan Accuracy yang dilakukan didapatkan hasil pada Tabel 7 bahwa, pada pengujian dengan jumlah data training 250 dan data testing 30 diperoleh nilai Precision 100\%, Recall 100\% dan Accuracy 100\%. Berikut ini rules yang terbentuk pada proses pengujian ini :

Tabel 8. Rules Yang Terbentuk Pada Pengujian Dengan Jumlah Data Training 250 kasus

\begin{tabular}{|c|c|}
\hline Rules ke & Detail Rules \\
\hline 1 & IF $($ BATUK $\geq 3$ MINGGU $=$ YA) AND $($ BB TURUN $=$ YA) THEN TBC $=$ YA \\
\hline 2 & $\begin{array}{l}\text { IF }(\text { BATUK } \geq 3 \text { MINGGU }=\text { YA) AND }(\text { BB TURUN }=\text { TIDAK) AND }(\text { NYERI DADA }= \\
\text { YA) THEN TBC }=\text { YA }\end{array}$ \\
\hline 3 & $\begin{array}{l}\text { IF }(\text { BATUK } \geq 3 \text { MINGGU }=\text { YA) AND }(\text { BB TURUN }=\text { TIDAK) AND }(\text { NYERI DADA }= \\
\text { YA) THEN TBC }=\text { TIDAK }\end{array}$ \\
\hline 4 & $\begin{array}{l}\text { IF }(\text { BATUK } \geq 3 \text { MINGGU }=\text { TIDAK) AND }(\text { KERINGAT MALAM = YA }) \text { AND } \\
(\text { KEADAAN RUMAH }=\text { BERSIH) AND }(\text { NYERI DADA }=\text { YA) THEN TB }=\text { YA }\end{array}$ \\
\hline 5 & $\begin{array}{l}\text { IF }(\text { BATUK } \geq 3 \text { MINGGU }=\text { TIDAK) AND }(\text { KERINGAT MALAM }=\text { YA) AND } \\
(\text { KEADAAN RUMAH }=\text { BERSIH) AND }(\text { NYERI DADA }=\text { TIDAK) THEN TB }=\text { TIDAK }\end{array}$ \\
\hline 6 & $\begin{array}{l}\text { IF }(\text { BATUK } \geq 3 \text { MINGGU }=\text { TIDAK }) \text { AND }(\text { KERINGAT MALAM }=\text { YA }) \text { AND } \\
(\text { KEADAAN RUMAH }=\text { KOTOR }) \text { THEN TB }=\text { TIDAK }\end{array}$ \\
\hline 7 & $\begin{array}{l}\text { IF }(\text { BATUK } \geq 3 \text { MINGGU }=\text { TIDAK) AND (KERINGAT MALAM }=\text { TIDAK }) \text { THEN TB }= \\
\text { TIDAK }\end{array}$ \\
\hline
\end{tabular}

Maka dari itu pada pengujian menggunakan data training 250 kasus dan data testing 30 kasus diperoleh hasil terbaik dengan nilai Precision, Recall, dan Accuracy maksimal dapat mencapai $100 \%$.

\subsection{Analisa Hasil}

Aplikasi prediksi penyakit Tuberkulosis (TBC) yang dibuat dengan menerapkan algoritma C4.5 memiliki 2 aktor utama yaitu administrator dan pengguna dengan hak akses yang berbeda. Administrator dapat mengelola semua data yang ada pada aplikasi meliputi pengolahan dataset tuberkulosis, perhitungan $\mathrm{C} 4.5$, melihat rules yang terbentuk, pengujian rules, dan pengolahan pertanyaan ke pengguna. Sedangkan untuk hak akses pengguna dapat melakukan prediksi penyakit tuberkulosis dengan cara menjawab beberapa pertanyaan yang diajukan. Dari jawaban yang diberikan oleh pengguna, aplikasi akan melakukan proses klasifikasi berdasarkan rules yang sudah terbentuk. Dari proses klasifikasi ini, akan didapatkan hasil apakah pengguna diprediksi terkena tuberkulosis atau tidak.

Pengujian dilakukan dengan 2 cara, yaitu pengujian blackbox dan pengujian Precision, Recall, dan Accuracy. Pada pengujian blackbox menunjukan bahwa semua modul yang ada pada aplikasi dapat berjalan sesuai dengan yang diharapkan. Pada pengujian Precision, Recall, dan Accuracy yang dilakukan dengan menggunakan data yang diperoleh dari Balai Kesehatan Paru Masyarakat Surakarta berjumlah 280 kasus menunjukan bahwa nilai rata rata maksimal yang didapatkan mencapai $100 \%$. Selain itu dari semua pengujian Precision, Recall, dan Accuracy yang telah dilakukan didapatkan bahwa semakin banyaknya data training maka nilai Precision, Recall, dan Accuracy yang diperoleh juga semakin meningkat. Sedangkan dari rules yang diperoleh didapatkan sebuah strong variabel yaitu Batuk $\geq 3$ Minggu dikarenakan variabel tersebut berada pada root node dari semua rules yang diperoleh. 


\section{KESIMPULAN DAN SARAN \\ 4.1 Kesimpulan}

Dari hasil penelitian yang telah dilakukan,didapatkan beberapa kesimpulan sebagai berikut :

1. Algoritma C4.5 berhasil digunakan untuk melakukan Prediksi Penyakit Tuberkulsosis (TBC), serta aplikasi yang dibuat berjalan dengan baik dan hasil yang didapatkan cukup baik.

2. Pada pengujian blackbox yang dilakukan, semua menu modul yang ada pada aplikasi berjalan dengan sangat baik, serta sesuai dengan fungsi yang diharapkan.

3. Pada pengujian Precision, Recall, dan Accuracy menunjukkan bahwa semakin banyaknya data training maka nilai Precision, Recall, dan Accuracy yang diperoleh juga semakin meningkat. Nilai rata - rata maksimal dari pengujian Precision,

4.2 Saran Recall, dan Accuracy yang didapatkan mencapai $100 \%$.

1. Memperbanyak sebaran data yang dapat diperoleh dari rumah sakit lainnya.

2. Untuk dapat mengoptimasi aplikasi ini, dapat digunakan metode yang berbeda ataupun digabungkan dengan metode lainnya. Supaya proses mining dan hasil yang didapatkan bisa lebih baik lagi.

\section{DAFTAR PUSTAKA}

Adhatrao, K., Gaykar, A., Dhawan, A., Jha, R., Honrao, V. (2013). Predicting Students' Performance Using ID3 And C4.5 Classification Algorithms. International Journal of Data Mining \& Knowledge Management Process, 3(5), 39-52. Doi: 10.5121/ijdkp.2013.3504

Amin, R. K., Indwiarti, Sibaroni, Y. (2015). Implementation of Decision Tree Using C4.5 Algorithm in Decision Making of Loan Application by Debtor (Case Study:Bank Pasar of Yogyakarta Special Region). Tersedia dari Information and Communication Technology (ICoICT ): 2015 3rd International Conference, Nusa Dua, Bali. IEEE. Doi: 10.1109/ICoICT.2015.7231400

Cheon, S. A., Cho, H. H., Kim, J., Lee, J., Kim, H., Park, T. J. (2016). Recent tuberculosis diagnosis toward the end TB strategy. Journal of Microbiological Methods, 123, 51-61. Doi:10.1016/j.mimet.2016.02.007

Deliu, I., Manea, E. (2014). The Incidence Of Mycobacterium Tuberculosis Infections And Resistance To AntiTuberculosis Drugs In Giurgiu Population. Current Trends in Natural Sciences, 3(6), 27-31.

Ekata., Tyagi, P. K., Gupta, N. K., Gupta, S. (2016). Diagnosis of Pulmonary Tuberculosis using Fuzzy Inference System. Innovative Applications of Computational Intelligence on Power, Energy and Controls with their Impact on Humanity (CIPECH-16), 3-7. Doi: 10.1109/CIPECH.2016.7918726

Eticha, B. M., Atomsa, A., Tsehaineh, B., Berheto, T. M. (2014). Patients' perspectives of the quality of tuberculosis treatment services in South Ethiopia. American Journal of Nursing Science, 3(4), 48-55. Doi: 10.11648/j.ajns.20140304.12

Hanik, U. (2011). Fuzzy Decision Tree dengan Algoritma C4.5 pada Data Diabetes Indian Pima, Institut Teknologi Sepuluh November. Surabaya.

Han, J., Kamber, M., Pei, J. (2011). Data mining : concepts and techniques (3rd ed.). USA: Morgan Kaufmann. 
Harryanto, F., Hansun, S. (2017). Penerapan Algoritma C4.5 untuk memprediksi Penerimaan Calon Pegawai Baru di PT WISE. Jatisi, 3(2), 95-103.

J. R. Quinlan, C4.5: Programs for Machine Learning, San Mateo: Morgan Kaufmann, 1993.

Kamagi, D. H., Hansun, S. (2014) Implementasi Data Mining dengan Algoritma C4.5 untuk Memprediksi Tingkat Kelulusan Mahasiswa. ULTIMATICS, 6(1), 15-20.

Kementrian Kesehatan Republik Indonesia. (2014). Pedoman Nasional Pengendalian Tuberkulosis. Tulisan pada : http://spiritia.or.id/dokumen/pedomantbnasional2014.pdf [Diakses pada 17 oktober 2017]

Kementrian Kesehatan Republik Indonesia. (2016). Berapa Kasus TBC di Indonesia?. Tulisan pada : http://databoks.katadata.co.id/datapublish/2017/03/22/berapa-kasustbc-di-indonesia [Diakses pada 17 oktober 2017]

Kumar, P. S., Umatejaswi, V. (2017). Diagnosing Diabetes using Data Mining Techniques. International Journal of Scientific and Research Publications, 7(6), 705-709.

Kurniawan, Y. I., Dwiyatmika, W. (2017). Aplikasi Diagnosa Retardasi Mental Pada Anak. Tersedia dari Prosiding SEMNAS Penguatan Individu di Era Revolusi Informasi.

Marwana. (2014). Algoritma C4.5 untuk Simulasi Prediksi Kemenangan Dalam Pertandingan Sepakbola, STIMED, Nusa Palapa, Makassar.

Padila. (2013). Asuhan Keperawatan Penyakit Dalam. Nuha Medika. Yogyakarta.

Purushottam., Saxena, K., Sharma, R. (2016). Efficient Heart Disease Prediction System using Decision Tree. International Conference on Computing, Communication and Automation (ICCCA2015), 85, 962-969. Doi:10.1016/j.procs.2016.05.288

Sandi, G., Supangkat, S. H., Slamet C. (2016). Health risk prediction for treatment of hypertension. Tersedia dari Cyber and IT Service Management: International Conference, Bandung, Indonesia. IEEE. Doi : 10.1109/CITSM.2016.7577584

World Health Organization. (2015). TB comorbidities and risk factors. Tulisan pada : http://www.who.int/tb/areas-of-work/treatment/risk-factors/en/ [Diakses pada 17 oktober 2017]

World Health Organization. (2016). The top 10 causes of death. Tulisan pada : http://www.who.int/mediacentre/factsheets/fs310/en/ [Diakses pada 17 oktober 2017]

World Health Organization. (2016). Global tuberculosis report 2016. Tulisan pada : http://www.who.int/tb/publications/global_report/en/ [Diakses pada 17 oktober 2017]

Zulvia, F., Kuo, R., Roflin, E. (2017). Efficient Heart Disease Prediction System using Decision Tree. IEEE, 204-209. Doi:10.1109/COMPSAC.2017.57. 